\section{Varying Plant Density and Harvest Time to Optimize Cowpea Leaf Yield and Nutrient Content}

\author{
Tracy A. Ohler ${ }^{1}$, S. Suzanne Nielsen ${ }^{2}$, and Cary A. Mitchell ${ }^{3}$ \\ NationalAeronautics and Space Administration Specialized Center of Research \\ and Training in Bioregenerative Life Support, Purdue University, West \\ Lafayette, IN 47907
}

Additional index words. Vigna unguiculata, bioregenerative life-support system, controlled ecological life-support system, shoot harvest index, yield-efficiency rate, total dietary fiber

\begin{abstract}
Plant density and harvest time were manipulated to optimize vegetative (foliar) productivity of cowpea [Vigna unguiculata (L.) Walp.] canopies for future dietary use in controlled ecological life-support systems as vegetables or salad greens. Productivity was measured as total shoot and edible dry weights (DW), edible yield rate [(EYR) grams DW per square meter per day], shoot harvest index [(SHI) grams DW per edible gram DW total shoot], and yield-efficiency rate [(YER) grams DW edible per square meter per day per grams DW nonedible]. Cowpeas were grown in a greenhouse for leaf-only harvest at 14, $28,42,56,84$, or 99 plants $/ \mathrm{m}^{2}$ and were harvested $20,30,40$, or 50 days after planting (DAP). Shoot and edible dry weights increased as plant density and time to harvest increased. A maximum of $1189 \mathrm{~g}$ shoot $\mathrm{DW} / \mathrm{m}^{2}$ and $594 \mathrm{~g}$ edible $\mathrm{DW} / \mathrm{m}^{2}$ were achieved at an estimated plant density of $85 \mathrm{plants} / \mathrm{m}^{2}$ and harvest 50 DAP. EYR also increased as plant density and

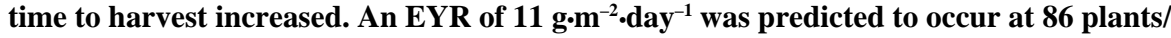
$\mathrm{m}^{2}$ and harvest 50 DAP. SHI and YER were not affected by plant density. However, the highest values of SHI $(64 \%)$ and YER $\left(1.3 \mathrm{~g}^{-\mathrm{m}^{-2}} \cdot \mathrm{day}^{-1} \cdot \mathrm{g}^{-1}\right)$ were attained when cowpeas were harvested 20 DAP. The average fat and ash contents [dry-weight basis (dwb)] of harvested leaves remained constant regardless of harvest time. Average protein content increased from $25 \%$ DW at 30 DAP to $45 \%$ DW at 50 DAP. Carbohydrate content declined from $50 \%$ DW at 30 DAP to $45 \%$ DW at 50 DAP. Total dietary fiber content (dwb) of the leaves increased from $19 \%$ to $26 \%$ as time to harvest increased from 20 to 50 days.
\end{abstract}

The controlled ecological life-support systems (CELSS) proposed for lunar and martian bases will rely on food crops for human nutrition, air revitalization, and water purification (Mitchell, 1993; Schwartzkopf, 1992). Because crop growth area and energy within the closed habitat will be limited, food production must be optimized, growth area minimized, and nonedible plant biomass recycled(Galston,

Received for publication 3 July 1995. Accepted for publication 14 Nov. 1995. Journal paper no. 14314 of the Purdue Univ., Agricultural Research Program. We gratefully acknowledge the assistance of MaryAnn Rounds, Steve Stephens, and John McKeehen, Dept. of Food Science, Purdue Univ., West Lafayette, Ind., for performing the leaf compositional analysis; B.B. Singh, International Institute of Tropical Agriculture, Kano, Nigeria, for providing cowpea germplasm; and Judy Santini, School of Agriculture Statistics Consultant, Purdue Univ., West Lafayette, Ind. Research supported in part by National Aeronautics and Space Administration grant NAGW-2329. The cost of publishing this paper was defrayed in part by the payment of page charges. Under postal regulations, this paper therefore must be hereby marked advertisement solely to indicate this fact.

${ }^{1}$ Graduate Research Assistant, Dept. of Horticulture. Current address: Dept. of Plants, Soils, and Biometeorology, Utah State Univ., Logan, UT $84322-4820$.

${ }^{2}$ Professor, Dept. of Food Science.

${ }^{3}$ Professor, Dept. of Horticulture. To whom reprint requests should be addressed.
1992). Cowpea is a low-fat candidate legume species for inclusion in CELSS. Vegetative harvest of cowpea provides an alternative to conventional cowpea seed harvest (Maeda, 1985) and a means to increase productivity while minimizing waste. Mixed harvest of seeds and leaves from the same plants is another option but may not result in the highest harvest index (proportion of edible biomass). Cowpea leaf harvest has a cropping time of only 21 to 42 days (Barrett, 1987), whereas cowpea seed requires 70 to 120 days (Duke, 1981). Leaf harvest would require environmental optimization only for a single phase of the cowpea cropping cycle and would use a larger percentage of shoot biomass than seed harvest (Bubenheim et al., 1990). High ediblebiomass production from a crop is less taxing on the energy-consumptive waste stream in a CELSS. Edible yield rate (EYR) of vegetative harvest, shoot harvest index (SHI), and yield efficiency rate (YER) of cowpea are unaffected by photoperiod (T.A.O. and C.A.M., unpublished). Therefore, photoperiod could be altered readily to meet air revitalization and water purification needs in a CELSS without compromising vegetative yield of cowpea.

The advantages of cowpea vegetative harvest also extend to the diet. In the United States, cowpea is grown primarily for its edible seeds (Wien and Summerfield, 1984). However, in Africa and Asia, young cowpea leaves also are harvested and consumed as a green vegetable (Barrett, 1987; Duke, 1981). Leaves and seeds are low in fat, high in carbohydrate, moderate in protein, and low in antinutritive factors. Like the protein in seeds, cowpea leaf protein complements that of cereal grains (Maeda, 1985). Leaves also are a good source of minerals, specifically $\mathrm{Fe}, \mathrm{Ca}$, K, and Zn (Imungiand Potter, 1983). Raw leaves are high in vitamin $\mathrm{C}$, carotene, and folacin, although $80 \%$ of these vitamins can be lost during cooking. Cooked cowpea leaves are suitable for further processing (Imungi and Potter, 1983), such as compacting and drying to create a rehydratable product with shelf life. Early inhabitants of a CELSS deployed in space will rely on a mainly vegetarian diet (Mitchell, 1994). Because species selection is expected to be limited, cowpea leaves could provide a more nutrient-dense food source than some other leafy vegetables proposed for CELSS.

When grown for leaf consumption, cowpeas generally are sown densely in the field (Barrett, 1987). Plants typically are harvested for foliage 3 to 6 weeks after planting. Cowpea canopy density is known to affect seed yield (Kwapata and Hall, 1990a, 1990b), but to our knowledge, edible leaf yield has not been measured at varied plant densities. However, increasing plant density of cowpeas grown for seed is known to increase shoot dry-matter production (Kwapata et al., 1990). Effects of harvest time on EYR, SHI, and YER for vegetative harvest are not known. Because green leaf index (number of green leaves per total leaves) decreases over time (Kwapata et al., 1990), time until harvest may affect EYR, SHI, and YER. Our objective was to determine which combinations of plant density and time until harvest would maximize these productivity characteristics for yield of edible leaves from a productive cowpea cultivar.

The proximate composition of cowpea leaves is known to change with leaf development (Bubenheim et al., 1990). As cowpea leaves aged, content of carbohydrate increased, protein decreased, and fat and ash remained constant. In our study, proximate composition and total dietary fiber (TDF) of cowpea leaves were measured periodically as cowpea canopies matured to help determine the optimum time for harvest.

\section{Materials and Methods}

The productive cowpea breeding line IT87D-941-1 (D-941) was used throughout our study, based on preliminary screening trials for vegetative harvest at Purdue Univ., West Lafayette, Ind. During Spring 1993 (April to June), D-941 was grown in a greenhouse at 1, 2, 3, 4, 6, or 7 plants/16-liter pot (Phoenix 2000X; Zarn, Reidsville, N.C.) (14, 28, 42, 56, 84 , or 99 plants $/ \mathrm{m}^{2}$, respectively). Plants were grown in a 2 peat : 2 perlite 1 soil (by volume) mixture amended with $890 \mathrm{~g} \mathrm{Ca}\left(\mathrm{H}_{2} \mathrm{PO}_{4}\right)_{2}, 593$ $\mathrm{g} \mathrm{MgSO}_{4}, 4.75 \mathrm{~kg}$ ground limestone, and 74.2 g Peters fritted trace elements no. 555 (W.R. Grace Co., Fogelsville, Pa.) $/ \mathrm{m}^{3}$ mix. Water and fertilizer were supplied three times daily (5 min each time) by a chapin capillary drip- 
irrigation system (Watermatics, Watertown, N.Y.). Nitrogen, K, and Ca were maintained at 201 (14.4 mM), 200 (5.1 mM), and 93 (2.3 mM) $\mathrm{mg} \cdot \mathrm{liter}^{-1}$, respectively, and $\mathrm{pH}$ at 6.8 in the injected solution. Greenhouse air averaged 38 $\pm 4 \mathrm{C}$ day $/ 25 \pm 3 \mathrm{C}$ night.

For $8 \mathrm{~h}$ daily ( $0830 \mathrm{HR}$ to $1630 \mathrm{HR}$ ), highpressure sodium lamps emitting a photosynthetic photon flux of $257 \pm 50 \mu \mathrm{mol} \cdot \mathrm{m}^{-2} \cdot \mathrm{s}^{-1}$ at canopy level were used to supplement natural sunlight. To prevent edge effects of side lighting on foliar yield of cowpea canopies, a black landscape fabric sleeve was raised to the top of each canopy as the plants grew. Sleeves were constructed to the same diameter as each pot.

Treatments included leaf harvest 20,30, 40 , or 50 days after planting (DAP). For the first two harvest treatments, all leaves were left on the plant for a single harvest 20 and 30 DAP, respectively. However, because cowpea leaves begin to senesce after 30 days of growth, fully expanded leaves were harvested at 10 -day intervals beginning $30 \mathrm{DAP}$. Flower buds were pinched off daily to maintain leaf production. For each treatment, all remaining leaves were stripped off at final harvest. In these studies, edible yield was taken as leafdry weight only. Experimental units were arranged in a randomized complete-block design with four blocked replications. Each blocked replication contained 24 units of six planting densities $\times$ four harvest times. Because the experiment contained quantitative treatment factor levels, treatment main effects and interactions were partitioned into orthogonal polynomial sources for the analysis of variance (ANOVA). Regression was performed on means of the highest-order interaction containing significant effects. Confidence intervals about the predicted values were computed to compare predicted values using half the least significant difference, taking into consideration the error variance due to the ANOVA and the regression.

Fresh weights of leaves and stems were recorded immediately after each harvest. Plant parts then were dried at $70 \mathrm{C}$ in forced-air drying ovens (Blue M Electric Co., Blue Island, Ill., or National Appliance Co., Portland, Ore.) for $48 \mathrm{~h}$, and dry weights were determined. Because fibrous roots could not be recovered quantitatively from the growth medium, roots were not harvested. Shoot harvest index was calculated as the proportion of edible (leaf) dry weight per total shoot dry weight within a canopy, EYR was calculated as the dry weight of leaves produced per unit canopy area per unit time, and YER was expressed as edible dry biomass produced per unit canopy area per unit time per unit nonedible dry biomass produced in the same space and period (Ohler and Mitchell, 1995).

For proximate composition and TDF procedures, all leaves harvested from a canopy were pooled. Dry plant material was ground in a Wiley mill (A.H. Thomas Co., Philadelphia) to pass a 20 -mesh $\left(1-\mathrm{mm}^{2}\right.$ pore size) screen. The ground tissue was redried for $12 \mathrm{~h}$ in a vacuum oven at $70 \mathrm{C}$ and $25 \mathrm{~mm} \mathrm{Hg}(3.3 \mathrm{KPa})$. Dried leaf samples were analyzed independently for fat, protein, ash, and TDF [Associa-

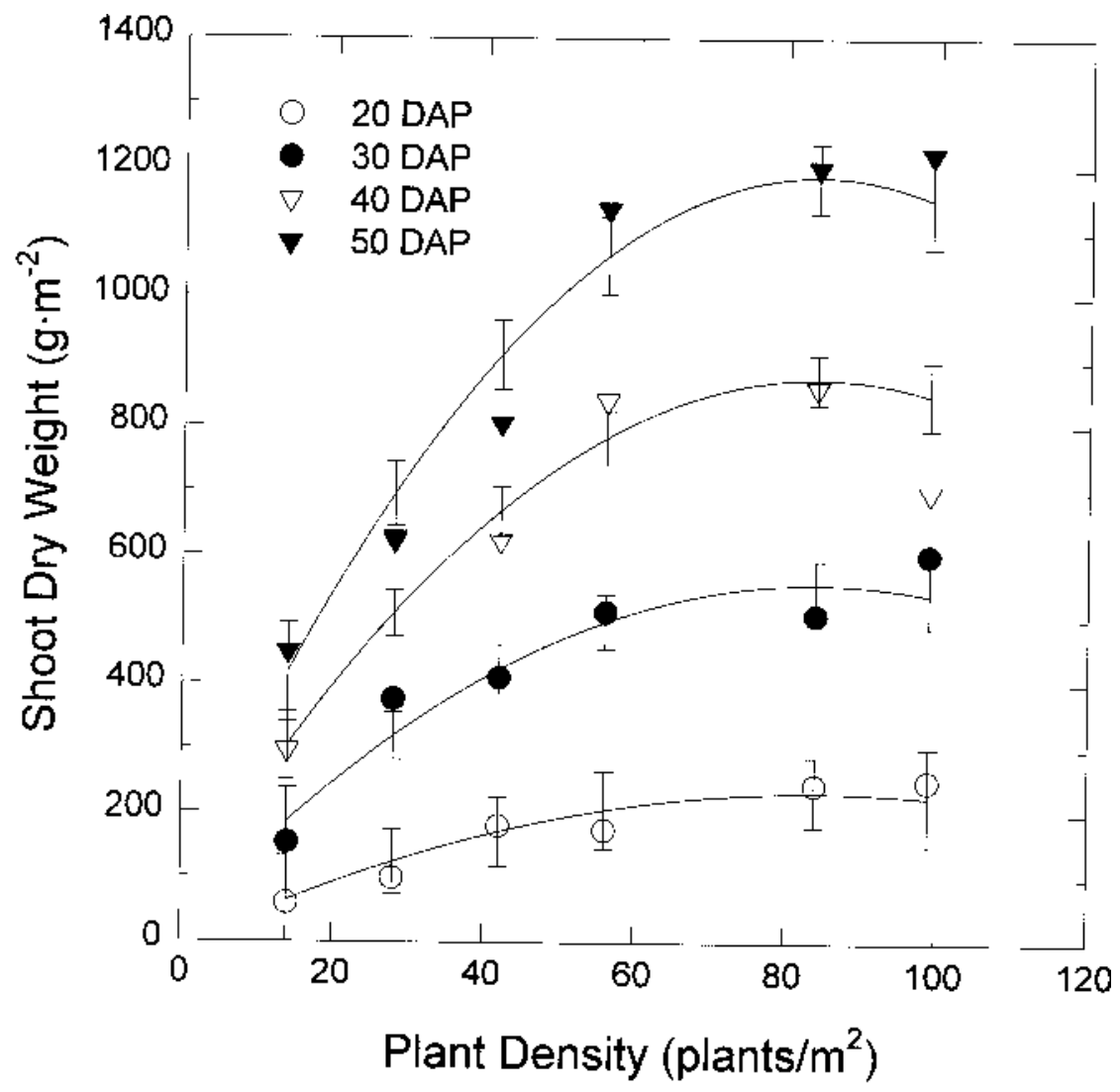

Fig. 1. Effect of plant density and harvest time on shoot dry weight of cowpea. Each point represents an average of four replications. Symbols represent the final harvest time in days after planting (DAP). Plotted lines are from regression analyses $\left(\mathrm{R}^{2}=0.97\right)$. Error bars equal half of the least significant difference at $P \leq 0.05$. Predicted values are significantly different where error bars do not overlap.

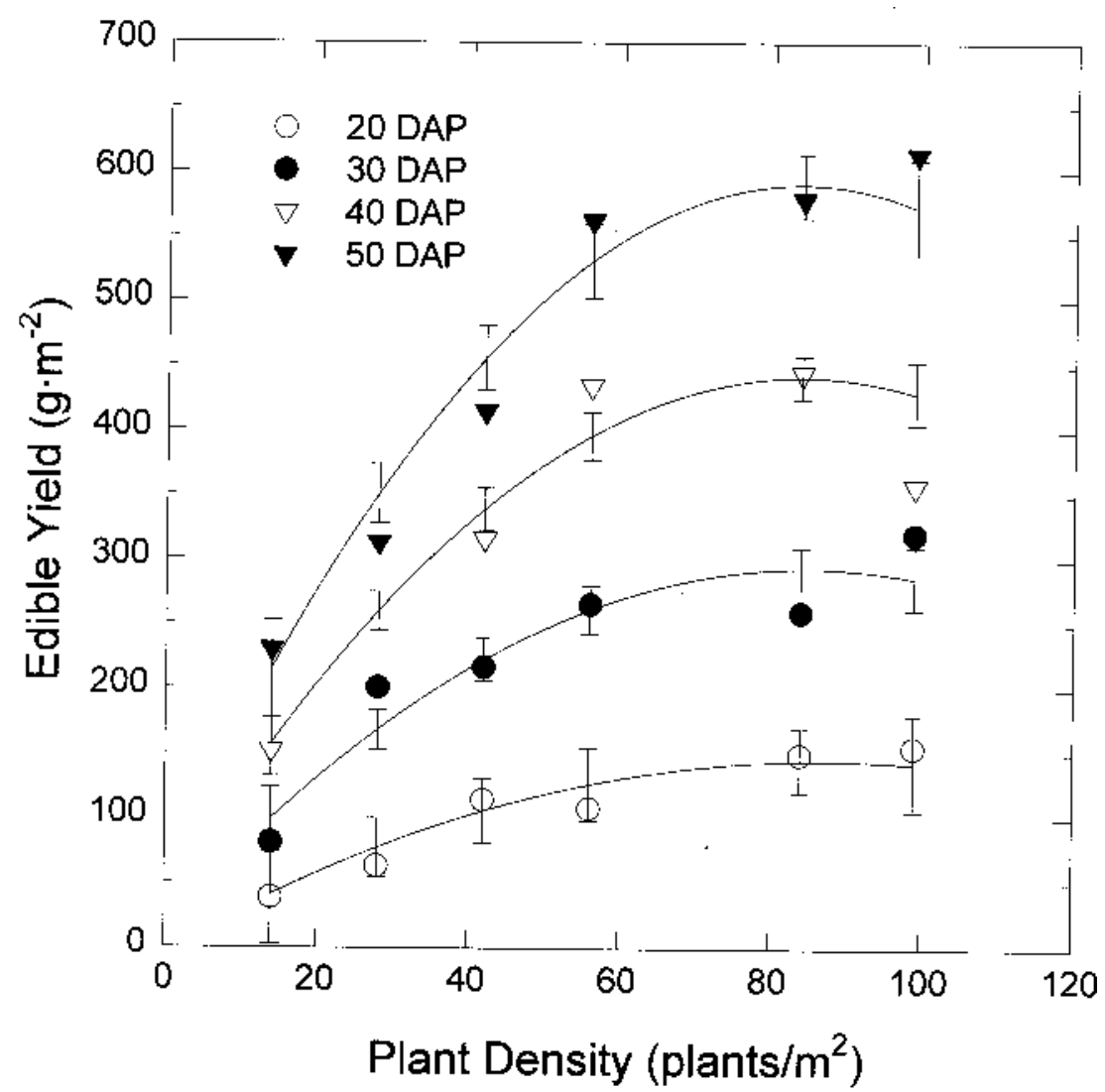

Fig.2.'Effect of plant density and'harvest time on edible yield of cowpea. Each point represents an average of four replications. Symbols represent the final harvest time in days after planting (DAP). Plotted lines are from regression analyses $\left(\mathrm{R}^{2}=0.97\right)$. Error bars equal half of the least significant difference at $P \leq$ 0.05 . Predicted values are significantly different where error bars do not overlap. 
tion of Official Analytical Chemists (AOAC), 1990]. Fat and ash determinations were performed in triplicate on subsamples, whereas protein and fiber assays used duplicate and quadruplicate subsamples, respectively. Fat content was determined by extracting 2- to 3 $\mathrm{g}$ samples with petroleum ether for $8 \mathrm{~h}$ in a soxhlet extraction unit. After evaporating solvent from the extraction flask, the fat remaining was weighed. Protein content was determined by a micro-Kjeldahl method using a conversion factor of 6.25 to convert percent $\mathrm{N}$ to percent protein. Proximate composition is reported on a dry-weight basis with carbohydrate content calculated by difference [percent $\mathrm{CHO}=100 \%-($ percent protein + percent fat + percent ash)]. Ash content was determined by weight after incinerating samples in a muffle furnace at $550 \mathrm{C}$ for $18 \mathrm{~h}$. TDF was determined using AOAC enzymatic-gravimetric method 985.29.

\section{Results and Discussion}

Shoot production. The harvest time $\times$ plant density interaction was significant for shoot dry weight (Fig. 1). At the lowest plant density tested (14 plants $/ \mathrm{m}^{2}$ ), shoot dry weight increased slightly as time to harvest increased, but harvest times 10 days apart were not significantly different from each other. However, for plant densities higher than 14 plants $/ \mathrm{m}^{2}$, shoot dry weight increased nonlinearly with time to harvest (Fig. 1). Higher shoot dry weight with longer time to harvest has been confirmed by others for cowpea (Brakke and Gardner, 1987; Kwapata and Hall, 1990b). Shoot dry weight of plants harvested 20 DAP was similar for all plant densities tested. However, for plants harvested 30, 40, or 50 DAP, shoot dry weight increased as density increased up to 85 plants $/ \mathrm{m}^{2}$. Below this density, the increase in shoot dry weight with increasing plant density became more pronounced the longer final harvest was delayed. Shoot biomass production approached $1200 \mathrm{~g} \cdot \mathrm{m}^{-2}$ at canopy densities of 80 to 100 plants $/ \mathrm{m}^{2}$ and harvest 50 DAP under the environmental conditions of this study.

Leaf production. The harvest time $\times$ plant density interaction was significant for edible yield (Fig. 2). At 14 plants $/ \mathrm{m}^{2}$, edible yield was similar for plants harvested 20 and 30 DAP or between plants harvested 40 and 50 DAP. At plant densities $>14$ plants $/ \mathrm{m}^{2}$, edible yield was significantly different for all harvest times. Longer times to final harvest increased edible yield. Differences in edible yield widened between harvest times as plant density increased up to 84 plants $/ \mathrm{m}^{2}$, above which it leveled. For all harvest times tested, except 20 DAP, edible yield increased with increasing plant density. This trend became more pronounced as time to final harvest lengthened. Edible biomass production approached 600 $\mathrm{g} \cdot \mathrm{m}^{-2}$ at canopy densities of 80 to 100 plants/ $\mathrm{m}^{2}$ and harvest 50 DAP.

Edible yield rate. For EYR, harvest time and plant density main effects were significant (Fig. 3). EYR averaged over all harvest times increased from 3 to $10 \mathrm{~g} \cdot \mathrm{m}^{-2} \cdot \mathrm{day}^{-1}$ as plant

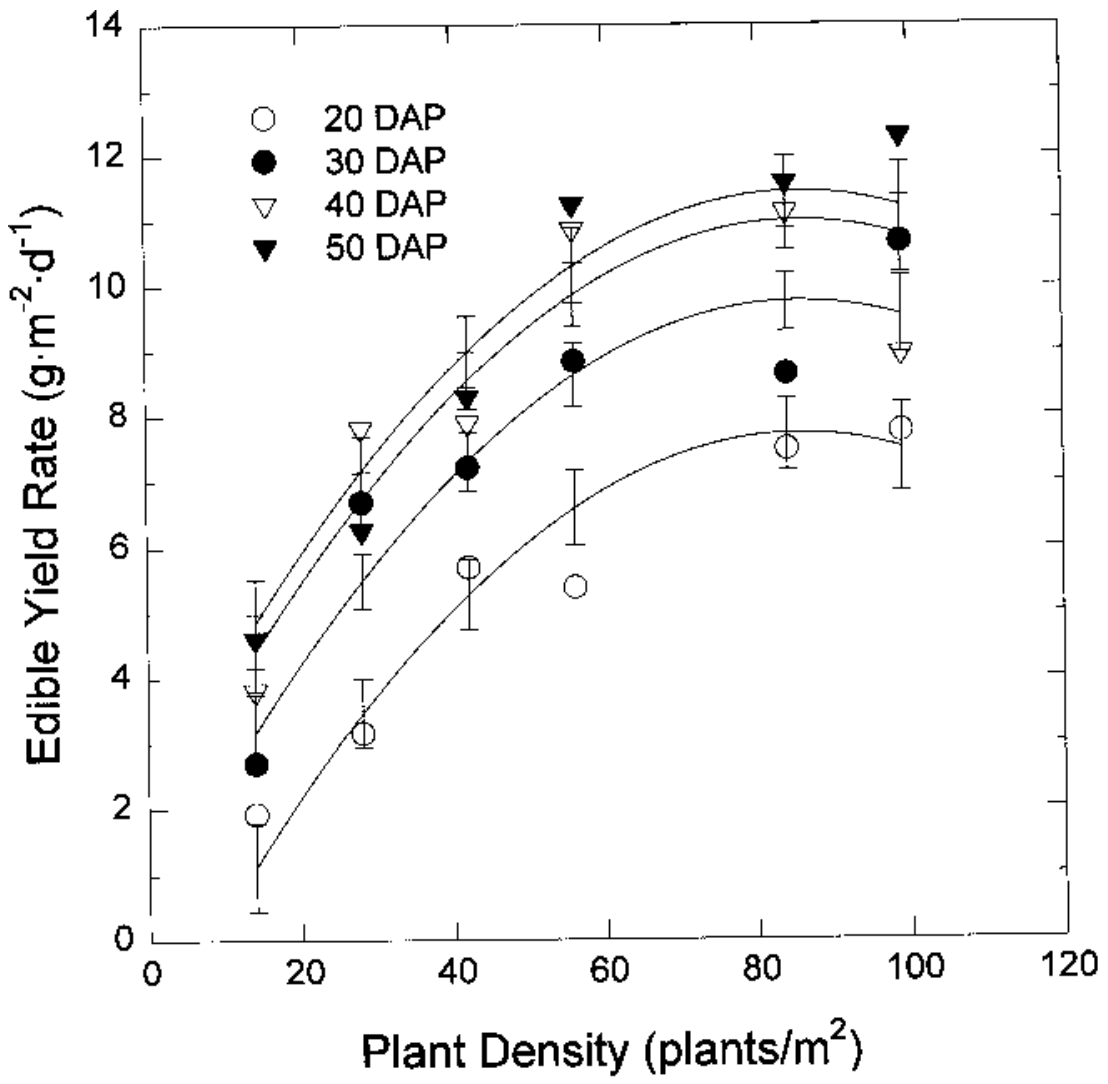

Fig. 3. Effect of plant density and harvest time on edible yield rate of "cowpea. Each" point represents an average of four replications. Symbols represent the final harvest time in days after planting (DAP). Plotted lines are from regression analyses $\left(\mathrm{R}^{2}=0.91\right)$. Error bars equal half of the least significant difference at $P \leq 0.05$. Predicted values are significantly different where error bars do not overlap.

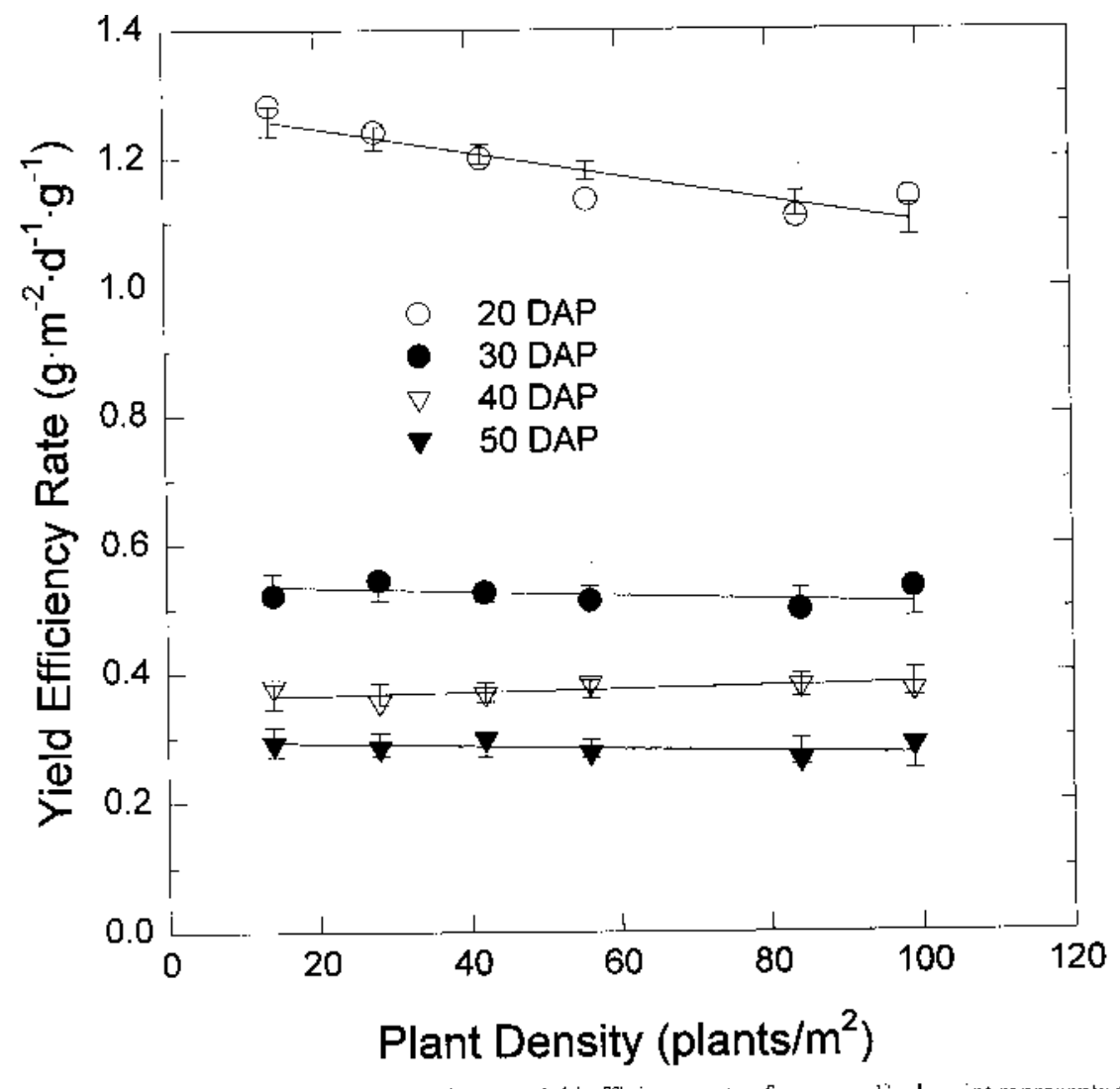

Fig. 4. Effect of plant density and harvest time on yield efficiency rate of cowpea. Each point represents an average of four replications. Symbols represent the final harvest time in days after planting (DAP). Plotted lines are from regression analyses $\left(\mathrm{R}^{2}=0.99\right)$. Error bars equal half of the least significant difference at $P \leq 0.05$. Predicted values are significantly different where error bars do not overlap. 
density increased from 14 to 99 plants $/ \mathrm{m}^{2}$, but it plateaued at a maximum value for all harvest times at $>56$ plants $/ \mathrm{m}^{2}$. EYR averaged over all plant densities increased from 5 to $9 \mathrm{~g} \cdot \mathrm{m}^{-2} \cdot$ day $^{-1}$ as time to harvest increased. However, EYRs of harvests at 40 and 50 DAP were not significantly different from each other. This result may have been due to a leaf area index (LAI) of three being sufficient for maximal light interception by cowpea canopies (Wien and Summerfield, 1984); in field stands of seven to 16 plants $/ \mathrm{m}^{2}$, a LAI of three was reached 34 to 40 DAP. At higher plant densities, a LAI of three was reached and lower leaves were mutually shaded by day 50 . Therefore, EYR was slowed, and the longer time to harvest became a heavier penalty. The lowest EYR was 2 $\mathrm{g} \cdot \mathrm{m}^{-2} \cdot$ day $^{-1}$ at 14 plants $/ \mathrm{m}^{2}$ and harvest 20 DAP. The highest EYR was $12 \mathrm{~g} \cdot \mathrm{m}^{-2} \cdot \mathrm{day}^{-1}$ at 99 plants $/ \mathrm{m}^{2}$ and harvest 50 DAP. From regression analysis, an EYR of $11 \mathrm{~g} \cdot \mathrm{m}^{-2} \cdot \mathrm{day}^{-1}$ is predicted at 86 plants $/ \mathrm{m}^{2}$ and harvest 50 DAP.

Only time to harvest significantly affected SHI. In contrast to EYR, which increased with time to harvest, SHI decreased from $64 \%$ to $50 \%$. When harvested 20 DAP, SHI $(64 \%)$ was significantly higher than at all other harvest times. Harvests 30, 40, and 50 DAP produced SHIs of $53 \%, 51 \%$, and $50 \%$ respectively, which were not significantly different from each other. Plant density did not significantly affect SHI. Kwapata and Hall (1990b) showed that SHI of cowpeas grown for seed was unaffected by plant density. As plant density increased, edible dry weight increased at the same rate as total shoot dry weight. The edible : nonedible biomass ratio remained constant, so SHI also remained constant as plant density increased. Therefore, a highdensity leaf canopy may be used to maximize EYR without adversely affecting SHI for leaf harvest. However, SHI decreased as harvest time increased, a response opposite the EYR trend.

Yield efficiency rate. Due to the reciprocal effect of harvest time on EYR and SHI, YER also was calculated. YER combines aspects of EYR and SHI to weigh edible yield against the penalties of cropping area, cropping time, and nonedible yield (Ohler and Mitchell, 1995). YERs for the four harvest times were significantly different from each other within planting density (Fig. 4). YER dropped from 1.3 to $0.3 \mathrm{~g} \cdot \mathrm{m}^{-2} \cdot \mathrm{day}^{-1} \cdot \mathrm{g}^{-1}$ as harvest time increased from 20 to 50 DAP at 14 plants $/ \mathrm{m}^{2}$. For plants harvested 20 DAP, YER decreased from 1.3 to $1.1 \mathrm{~g} \cdot \mathrm{m}^{-2} \cdot \mathrm{day}^{-1} \cdot \mathrm{g}^{-1}$ as plant density increased from 14 to 99 plants $/ \mathrm{m}^{2}$. YERs of $0.5,0.4$, and $0.3 \mathrm{~g} \cdot \mathrm{m}^{-2} \cdot \mathrm{day}^{-1} \cdot \mathrm{g}^{-1}$ remained constant under all plant densities tested when plants were harvested 30, 40, or 50 DAP, respectively. Therefore, higher plant densities can be used to optimize EYR without affecting SHI and YER negatively. Using higher plant densities has the added advantage of more rapid canopy closure. Canopy closure results in more photosynthetically active radiation intercepted per unit canopy cover (ground) area, thereby conserving energy in a CELSS. A maximum YER of $1.3 \mathrm{~g} \cdot \mathrm{m}^{-2} \cdot \mathrm{day}^{-1} \cdot \mathrm{g}^{-1}$ occurred at 14 plants $/ \mathrm{m}^{2}$ and harvest 20 DAP. Nonedible biomass from

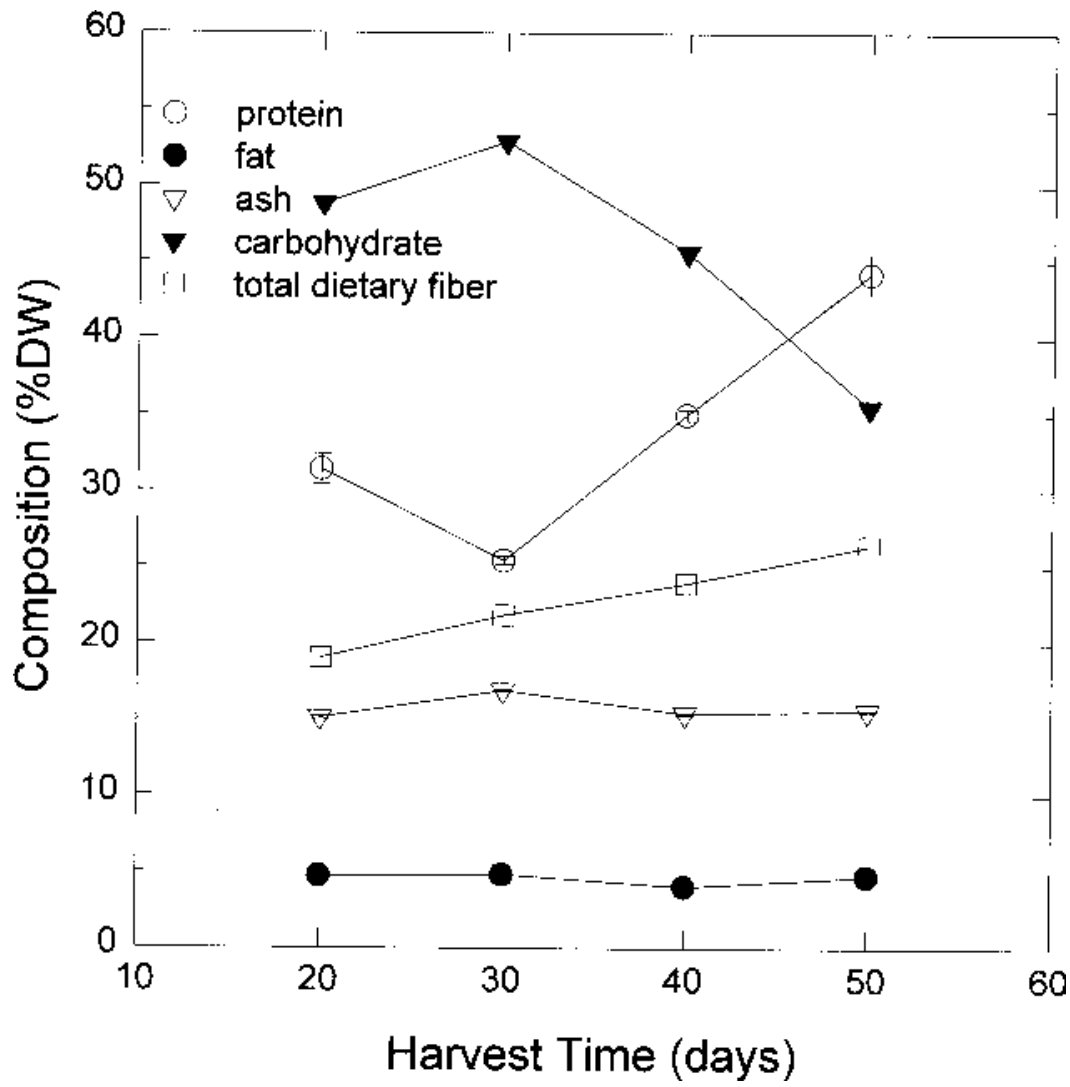

Fig. 5. Effect of harvest time on proximate composition and total dietary fiber of cowpea leaves. Each point represents an average of three replications. Some sDS are smaller than the symbols representing each point.

20-day-old plants likely would be easier to recycle to renewable resources in a CELSS than would the more lignified tissues of older plants.

Shoot composition. Proximate composition and TDF of 40- and 50-day-old plants included that of leaves removed at 10-day intervals before final harvest. Therefore, the average age of leaves harvested from 40 - and 50-day canopies was less than that of leaves harvested from 30-day canopies. Fat and ash contents remained constant regardless of harvest time (Fig. 5). Protein content decreased from $31 \%$ to $25 \%$ (dry-weight basis) as harvest time increased from 20 to 30 DAP. Protein contents of $35 \%$ and $44 \%$ for harvests 40 and 50 DAP, respectively, were higher than for harvests at 20 and 30 DAP. Carbohydrate content increased from $49 \%$ to $53 \%$ as harvest time increased from 20 to 30 DAP. Carbohydrate levels decreased to $46 \%$ and $36 \%$ for harvests 40 and $50 \mathrm{DAP}$, respectively. TDF increased from $19 \%$ to $26 \%$ as harvest time increased. For a vegetarian diet component with high carbohydrate, moderate protein, low fat, and moderate TDF, harvesting 20 DAP is recommended. If a higher TDF level is desired, harvesting at 40 DAP would produce levels of carbohydrate, protein, and fat similar to those of a harvest 20 DAP but would produce a higher TDF content.

\section{Conclusion}

The most productive vegetative harvest for cowpea grown in a greenhouse in our study was obtained with an early harvest date (20 DAP) and 84 to 99 plants $/ \mathrm{m}^{2}$. A cowpea canopy under these conditions produced an EYR of 11 $\mathrm{g} \cdot \mathrm{m}^{-2} \cdot$ day $^{-1}$, a SHI of $64 \%$, and a YER of 1.3 $\mathrm{g} \cdot \mathrm{m}^{-2} \cdot \mathrm{day}^{-1} \cdot \mathrm{g}^{-1}$. Experiments with cowpea in completely controlled environments are required to determine upper limits of productivity for this crop. However, studies in the more extensive, semi-controlled environment of greenhouses permit simultaneous comparisons of multiple treatments with adequate replication and permit comparison of cultural variables as in our study.

\section{Literature Cited}

Association of Official Analytical Chemists. 1990. Official methods of analysis. 15th ed. Assn. Offic. Anal. Chemists, Arlington, Va.

Barrett, R.P. 1987. Integrating leaf and seed production strategies for cowpea (Vigna unguiculata (L.) Walp.). MS Thesis, Michigan State Univ., East Lansing.

Brakke, M.P. and F.P. Gardner. 1987. Juvenile growth in pigeonpea, soybean, and cowpea in relation to seed and seedling characteristics. Crop Sci. 27:311-316.

Bubenheim, D.L., C.A. Mitchell, and S.S. Nielsen. 1990. Utility of cowpea foliage in a crop production system for space, p. 535-538. In: J. Janick and J.E. Simon (eds.). Advances in new crops. Timber Press, Portland, Ore.

Duke, J., C. Reed, K. Rachie, and R. Summerfield. 1981. Vigna unguiculata (L.) Walp. ssp. unguiculata, p. 302-306. In: J. Duke (ed.). Handbook of legumes of world economic importance. Plenum Press, New York.

Galston, A.W. 1992. Photosynthesis as a basis for 
life support on earth and in space. BioScience 42(7):490-493.

Imungi, J.K. and N.N. Potter. 1983. Nutrient contents of raw and cooked cowpea leaves. J. Food Sci. 48:1252-1254.

Kwapata, M.B. and A.E. Hall. 1990a. Response of contrasting vegetable-cowpea cultivars to plant density and harvesting of young green pods. I. Pod production. Field Crops Res. 24:1-10.

Kwapata, M.B. and A.E. Hall. 1990b. Determinants of cowpea (Vigna unguiculata) seed yield at extremely high plant density. Field Crops Res. 24:23-32.

Kwapata, M.B., A.E. Hall, and M.A. Madore. 1990.
Response of contrasting vegetable-cowpea cultivars to plant density and harvesting of young green pods. II. Dry matter production and photosynthesis. Field Crops Res. 24:11-21.

Maeda, E.E. 1985. Effect of solar dehydration on amino acid pattern and available lysine content in four tropical leafy vegetables. Ecol. Food Nutr. 16:273-279.

Mitchell, C.A. 1993. The role of bioregenerative life-support systems in a manned future in space. Trans. Kansas Acad. Sci. 96(1-2):87-92.

Mitchell, C.A. 1994. Bioregenerative life-support systems. Amer. J. Clinical Nutr. 60:820S-824S.
Ohler, T.A. and C.A. Mitchell. 1995. Effects of carbon dioxide level and plant density on cowpea canopy productivity for a bioregenerative life-support system. Life Support \& Biosphere Sci. J. 2:3-9.

Schwartzkopf, S.H. 1992. Design of a controlled ecological life support system. BioScience 42(7):526-535.

Wien, H.C. and R.J. Summerfield. 1984. Cowpea (Vigna unguiculata (L.) Walp.), p. 353-383. In: P.R. Goldsworthy and N.M. Fisher (eds.). The physiology of tropical field crops. Wiley, Chichester, England. 